\title{
In-situ Measurements of Tropospheric Hydroxyl Radicals by Folded Long-Path Laser Absorption During the Field Campaign POPCORN
}

\author{
UWE BRANDENBURGER ${ }^{\star}$, THEO BRAUERS, HANS-PETER DORN ${ }^{\star \star}$, \\ MARTIN HAUSMANN and DIETER H. EHHALT \\ Institut für Atmosphärische Chemie, Forschungszentrum Jülich GmbH, Germany
}

(Received: 10 March 1997; in final form: 10 December 1997)

\begin{abstract}
Absolutely calibrated in-situ measurements of tropospheric hydroxyl radicals, formaldehyde, sulfur dioxide, and naphthalene $\left(\mathrm{C}_{10} \mathrm{H}_{8}\right)$ were performed by long-path laser absorption spectroscopy during the field campaign POPCORN. The absorption light path was folded into an open optical multiple reflection cell with a mirror separation of $38.5 \mathrm{~m}$. Using a light path length of $1848 \mathrm{~m}$ and an integration time of $200 \mathrm{~s}$, the average $1 \sigma$-detection limits of $\mathrm{OH}, \mathrm{HCHO}, \mathrm{SO}_{2}$ and $\mathrm{C}_{10} \mathrm{H}_{8}$ during POPCORN were $8.7 \cdot 10^{5} \mathrm{~cm}^{-3}, 8.3 \cdot 10^{9} \mathrm{~cm}^{-3}, 2.4 \cdot 10^{9} \mathrm{~cm}^{-3}, 1.5 \cdot 10^{8} \mathrm{~cm}^{-3}$, respectively. In total, 392 identifications of $\mathrm{OH}$ in air spectra were made in a rural environment between August 5 and August 23, 1994. We present and discuss $\mathrm{OH}$ absorption spectra and diurnal $\mathrm{OH}$ concentration profiles of three days which are representative for measurements under different pollution conditions during POPCORN. The observed maximum and median $\mathrm{OH}$ radical concentrations are $1.3 \cdot 10^{7} \mathrm{OH} / \mathrm{cm}^{3}$ and $4.0 \cdot 10^{6} \mathrm{OH} / \mathrm{cm}^{3}$, respectively. The measured diurnal variation of the $\mathrm{OH}$ concentration shows a good correlation with the primary formation reaction of $\mathrm{OH}$ radicals which is the photolysis of ambient ozone. Deviations from this correlation in the morning and evening hours, when the $\mathrm{OH}$ concentration is higher than expected from the ozone photolysis, demonstrate the importance of other photochemical $\mathrm{HO}_{x}$ production pathways during POPCORN.
\end{abstract}

Key words: tropospheric hydroxyl radicals, laser absorption spectroscopy, OH-radical chemistry, field experiment.

\section{Introduction}

Since the first successful measurement of tropospheric $\mathrm{OH}$ radicals by long-path laser absorption in the early 1980s (Perner et al., 1987) several instruments based on different detection principles were developed (for an overview see Crosley, 1994). Among those only the spectroscopic detection of OH by long-path laser absorption provides absolutely calibrated $\mathrm{OH}$ measurements. This technique is based on the principle of differential optical absorption spectroscopy (DOAS) which is an inherently calibrated method. Several $\mathrm{OH}$ absorption instruments were developed

\footnotetext{
^ Now at: SERCON, München, Germany.

$\star \star$ Address for correspondence: Dr. Hans-Peter Dorn, Institut für Atmosphärische Chemie, Forschungszentrum Jülich, 52425 Jülich, Germany, h.p.dorn@fz-juelich.de
} 
in the last 15 years. They differ in the type of laser and detector used (Platt et al., 1988; Dorn et al., 1988; Neuroth, 1992; Mount, 1992; Armerding et al., 1994).

Even though, the number of published $\mathrm{OH}$ absorption measurements is still rather sparse. Because of the very low $\mathrm{OH}$ concentration in ambient air, the resulting absorbance signal of $\mathrm{OH}$ radicals is very weak and comes close to the technical limits of photo detectors. In the following we present a substantial set of groundbased $\mathrm{OH}$ measurements which were performed in August 1994 during the field campaign POPCORN (Photochemistry of Plant Emitted Compounds and $\mathrm{OH}$ Radicals in North-Eastern Germany). $392 \mathrm{OH}$ data were measured with a newly developed long-path laser absorption instrument (Brandenburger, 1995; Hausmann et al., 1997). The apparatus used a multiple folded light path which allowed $\mathrm{OH}$ absorption measurements in a relatively small air volume close to the volume sampled by another $\mathrm{OH}$ measurement technique used during POPCORN (Holland et al., this issue).

The POPCORN campaign aimed to provide a comprehensive investigation of the local fast photochemical processes which affect the ambient concentration of free $\mathrm{OH}$ radicals in the planetary boundary layer (for an overview of the field experiment see Plass et al., this issue). The $\mathrm{OH}$ field measurements were performed under different levels of air pollution (Brauers et al., and Koppmann et al., both this issue). We will discuss three examples of absorption measurements under conditions which range from clean to polluted air.

Another main issue of POPCORN was to compare long-path $\mathrm{OH}$ absorption measurements with $\mathrm{OH}$ data determined by laser-induced fluorescence (LIF) (Hofzumahaus et al., 1996, Holland et al., this issue). Both laser spectroscopic in-situ $\mathrm{OH}$ detection techniques were developed in our institute and were applied in the field for the first time during this campaign. The results of the instrument intercomparison are described by Brauers et al. (1996) and Hofzumahaus et al., this issue).

\section{Experimental}

\subsection{THE OH LONG-PATH ABSORPTION INSTRUMENT}

Figure 1 illustrates the setup of the experiment which is described in detail by Hausmann et al. (1997). The DOAS instrument consists of the laser light source, the detection light path in the atmosphere, the high resolution spectrograph, and the optical multi channel detector to record the spectra.

The light source is a frequency doubled picosecond dye laser which emits a broad spectral profile with a half width of $0.41 \mathrm{~nm}$ at $308 \mathrm{~nm}$. Because of the very low concentration of tropospheric $\mathrm{OH}$ in the $10^{6} \mathrm{molecules} / \mathrm{cm}^{3}$ range, an absorption light path of about one kilometer or more is required for a sufficiently sensitive detection. This is realized by folding the light path into an open optical multiple reflection cell, MRC, which had a mirror separation of $38.5 \mathrm{~m}$. With this cell, absorption path lengths of $616 \mathrm{~m}, 1848 \mathrm{~m}$ and $3080 \mathrm{~m}$ can be realized. The use 


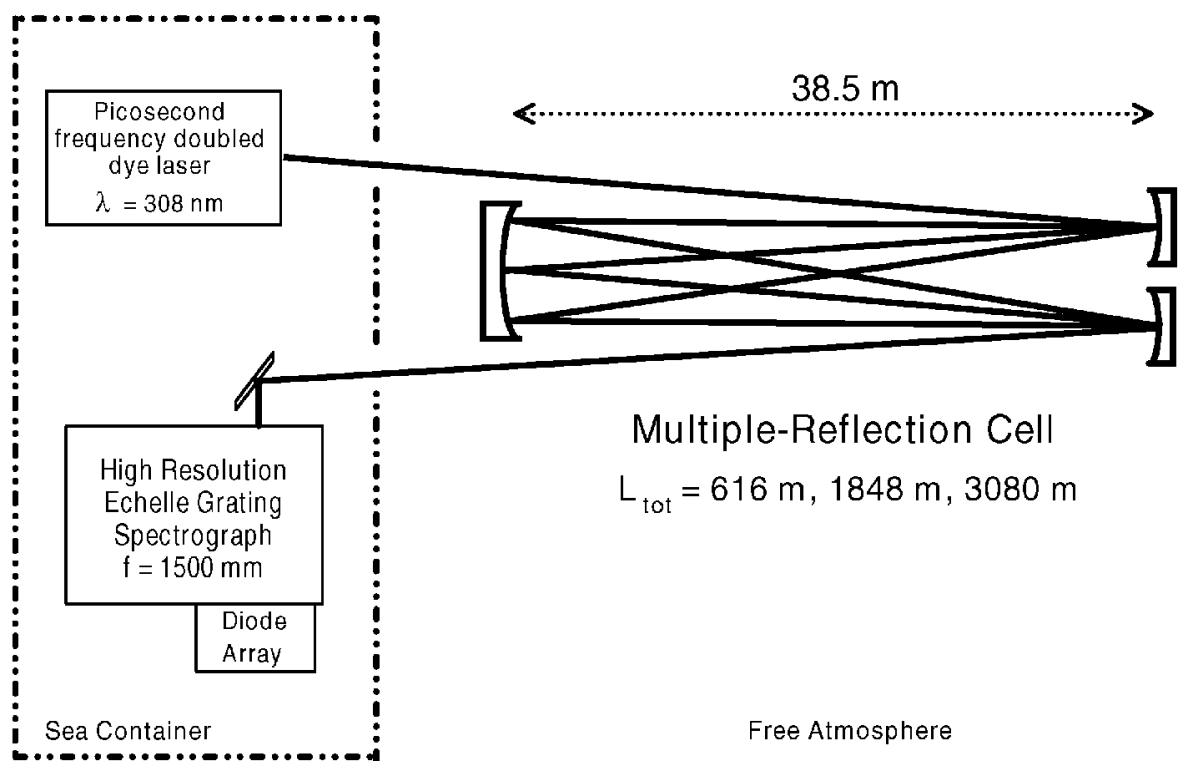

Figure 1. Experimental setup for the in-situ $\mathrm{OH}$ radical detection by folded long-path laser absorption spectroscopy utilizing an optical multiple-reflection cell of $38.5 \mathrm{~m}$ base length. Laser light source and diode array spectrometer are located in a sea container.

of a MRC allows to perform absolute measurements of $\mathrm{OH}$ radicals in defined air parcels.

Absorption spectra are recorded with the help of a high resolution Echelle grating spectrograph coupled to a linear photodiode array detector. This technique in combination with the broadband laser allows to record a spectral interval of $0.22 \mathrm{~nm}$ which covers 6 atmospheric $\mathrm{OH}$ absorption lines simultaneously (Dorn et al., 1995a). This is the largest spectral range ever used for atmospheric $\mathrm{OH}$ detection by long-path laser absorption spectroscopy. As we will show, the broad-band detection considerably improves the specificity of the $\mathrm{OH}$ detection.

The technique uses Lambert-Beer's law to calculate the concentration $C$ from the measured optical density $D$ making DOAS a direct and absolute $\mathrm{OH}$ detection method:

$$
D(\lambda)=\ln \frac{I_{0}(\lambda)}{I(\lambda)}=\sigma(\lambda) \cdot L \cdot C
$$

( $D=$ Differential optical density (absorbance); $I(\lambda), I_{0}(\lambda)=$ received light intensity with and without absorption of a molecule at a particular wavelength; $\sigma(\lambda)=$ differential absorption cross section; $L=$ light path length; $C=$ concentration of trace gas.)

All spectra during POPCORN were measured using the "multiple channel scanning technique, MCST' (see Section 2.5 and Brauers et al., 1995). The only parameter which must be known a priori is the differential absorption cross section $\sigma(\lambda)$ of the observed molecules for this instrument (see Section 2.5). 


\subsection{INSTRUMENTAL SETUP IN THE FIELD}

The measurement site was in the neighborhood of the village Pennewitt $\left(53.81^{\circ} \mathrm{N}\right.$, $11.75^{\circ} \mathrm{E}, 50$ inhabitants) in NE Germany, about $15 \mathrm{~km}$ south of the Baltic Sea shore line. Laser system and detection unit were located in a sea container. The MRC mirrors were positioned in the corn field on two tubular steel scaffolds such that the light path was running about $4 \mathrm{~m}$ above ground and $2.5 \mathrm{~m}$ above the corn canopy. The absorption path was oriented in SW-NE direction diagonally to the predominant wind directions (west and east during the campaign) (for details concerning the site see Brauers et al., Plass et al., and Hofzumahaus et al., this issue).

The integration times necessary to record an $\mathrm{OH}$ spectrum varied between $100 \mathrm{~s}$ and $1000 \mathrm{~s}$ during the field experiment. The majority of spectra was recorded with $200 \mathrm{~s}$ integration time. In order to avoid nonlinear effects of the detector, the integration time for a single readout was generally chosen such that the individual diode signal reached about $40-50 \%$ of the saturation value.

The light path length was mostly set to $1848 \mathrm{~m}$. Only a few measurements were made at a path length of $3080 \mathrm{~m}$ because with the optical setup used at that time light losses occurred at the prisms of the multiple reflection cell when it was set to the longest light path possible.

\subsection{REFERENCE SPECTRA OF ATMOSPHERIC TRACE GASES}

The atmospheric trace gases sulfur dioxide, formaldehyde, and naphthalene possess spectrally well resolved absorption lines in the ultraviolet spectral region around $308 \mathrm{~nm}$ where tropospheric $\mathrm{OH}$ is detected. Thus, spectral lines of these trace gases are often superimposed on the absorption spectra of $\mathrm{OH}$, in particular recognizable under polluted conditions. The relative contribution of each species to an air spectrum depends on its concentration and the individual absorption cross section. From the resulting composite spectra, the concentration data are obtained by multicomponent analysis. This evaluation technique requires very accurate reference spectra of $\mathrm{OH}$ and the other absorbing trace gases. The reference spectra must be recorded under the conditions of the actual field measurements because, at least for $\mathrm{OH}$ and $\mathrm{HCHO}$, the absorption cross sections depend on pressure and temperature (Dorn et al., 1995b; Cantrell et al., 1990).

$\mathrm{OH}$ reference spectra were recorded within the multiple reflection cell with the help of a low pressure mercury $\operatorname{lamp}(\lambda=184.9 \mathrm{~nm})$ which was operated in front of the field mirror of the MRC and photolysed atmospheric water molecules (mixing ratio 1-3\%) generating $\mathrm{OH}$ radicals in thermal equilibrium with the environment. The spectra were measured with a light path length of $1848 \mathrm{~m}$, thus the irradiated volume in which $\mathrm{OH}$ radicals are generated in high concentration was passed 48 times by the detection laser beam. This resulted in a total $\mathrm{OH}$ absorbance of about $3 \cdot 10^{-3}(S / N \geq 100)$. The reference spectra of sulfur dioxide, formaldehyde and naphthalene were either measured by positioning an open windowless glass tube $(20 \mathrm{~cm})$ into the UV laser beam and flushing the tube with the respective gases 
diluted in synthetic air or by placing sealed quartz cells $(L=10 \mathrm{~cm})$ into the laser beam which were filled with the pure gases diluted with synthetic air at atmospheric pressure. The sealed cells were equipped with Brewster windows in order to avoid modulation of the transmitted light intensity by etalon effects. In each case the concentration of the calibration gases was such that the resulting differential absorption was in the order of $10^{-3}$. Each spectrum was finally divided by an air spectrum measured under the same ambient conditions immediately before or after but without the reference gas in the laser beam, in order to correct for absorption of atmospheric components along the light path. Examples of reference spectra can be found in Dorn et al. (1996).

\subsection{EVALUATION OF ABSORPTION SPECTRA}

The individual contributions of each trace gas to an atmospheric absorption spectrum are obtained by multicomponent analysis using the measured reference spectra. The whole set of reference spectra and a polynomial (of 7th order), which corrects for a potential curvature of the spectral baseline, are least-squares fitted simultaneously to the measured air spectra over a spectral range of $0.22 \mathrm{~nm}(850$ detector pixels) (Gomer et al., 1993). Thus, all the absorption lines due to these molecules, including their relative shapes and strengths, are used for the identification and the quantitative determination of each component contributing to the observed spectrum.

The solutions of the least-squares procedure give the estimators for the best fit if the residual spectral noise is normally distributed (Press et al., 1992). From the resulting individual fit coefficients and from the known line strength of the reference spectrum the optical density of each compound at any spectral position can be calculated. Finally the concentration of each trace gas is determined by Lambert-Beer's law using the appropriate differential absorption cross sections and the known light path length.

The simultaneous fit of all components is essential for a precise concentration measurement since some trace gases, in particular $\mathrm{OH}$ and formaldehyde, possess inverse absorption structures (see Dorn et al., 1996). Thus, if HCHO is present in ambient air in a certain concentration the $\mathrm{OH}$ absorption lines can appear significantly reduced (an example is shown in Figure 3(II) below). To solve this problem the investigated spectral interval must be large enough to avoid ambiguity. In contrast to our former OH instrument (Callies, 1988; Neuroth, 1992) which had a spectral range of only $0.06 \mathrm{~nm}$, the observation of a $0.22 \mathrm{~nm}$ interval provides more spectral information for the evaluation of superimposed absorption spectra resulting in an improved specificity and in a higher precision of the measurements. 


\subsection{ACCURACY OF OH-DOAS. THE DIFFERENTIAL ABSORPTION CROSS SECTIONS OF OH, HCHO, $\mathrm{SO}_{2}$, AND $\mathrm{C}_{10} \mathrm{H}_{8}$}

DOAS is based on Lambert-Beer's law of absorption. Thus, the accuracy of DOAS measurements is mainly determined by the accuracy of the differential absorption cross sections used. It was shown that the effective absorption cross sections of the $\mathrm{OH}$ absorption lines can be calculated with high accuracy using the well known molecular constants of the $\mathrm{OH}$ molecule and the actual atmospheric pressure and temperature data during the measurements (Dorn et al., 1995b; Hausmann et al., 1997).

The high resolution differential absorption cross sections of formaldehyde, sulfur dioxide and naphthalene can not be calculated and were determined in calibration experiments in the laboratory using quartz cells filled with the reference gases in synthetic air at atmospheric conditions. The actual concentration in the cells was monitored by simultaneous measurements with a low resolution DOAS technique on the basis of the known trace gas absorption coefficients at low spectral resolution (Neuroth et al., 1991; Neuroth, 1992).

The high resolution cross sections determined as described must be further corrected when the 'multi channel scanning technique, MCST' is applied for the recording of the absorption spectra as was done during POPCORN. The principle of MCST is described in detail by Brauers et al. (1995). Compared to 'standard' OH long-path measurements in the past (Dorn et al., 1993; Ehhalt et al., 1994) the use of MCST has led to a reduction of the residual noise in atmospheric absorption spectra by about an order of magnitude which relates to a corresponding decrease of the detection limit. However, the application of MCST slightly modifies the shape of the absorption spectra (Brauers et al., 1995) and this leads to a reduction of the effective absorption cross sections compared to the standard DOAS technique. Fortunately this effect is well defined and reproducible and is therefore taken into account in the determination of the final absorption cross sections (Table I). Thus, MCST does actually not affect the accuracy of the DOAS technique (see Hausmann et al., 1997).

For the experimental conditions during POPCORN (entrance slit width of the spectrograph was $60 \mu \mathrm{m}$ ) the effective $\mathrm{OH}$ absorption cross section at the line center of the $Q_{1}(2)$ absorption line (at $307.9951 \mathrm{~nm}$ ) is $\sigma=(9.87 \pm 0.7) \cdot 10^{-17} \mathrm{~cm}^{2}$. The uncertainty of less than $6.5 \%$ includes the $3 \%$ total error of the absorption line strength (Dorn et al., 1995b), the error caused by the mismatch of the lineshapes of calculated and measured $\mathrm{OH}$ spectrum, and the error of the light path length determination (Hausmann et al., 1997).

The high accuracy of long-path absorption spectroscopy allows to use this technique as a reference method against which other in-situ techniques can be well compared and calibrated (Dorn et al., 1995b; Mount, 1992; Mount and Eisele, 1992; Eisele et al., 1994). 
Table I. Differential absorption cross sections for selected lines of $\mathrm{OH}$, formaldehyde, sulfur dioxide, and naphthalene. The cross sections were used for the data evaluation of POPCORN measurements and include the influence of the multichannel scanning technique (see text).

\begin{tabular}{lll}
\hline Trace gas & Absorption cross section & Wavelength of selected absorption line \\
\hline $\mathrm{OH}$ & $(9.87 \pm 0.70) \cdot 10^{-17} \mathrm{~cm}^{2}$ & $307.9951 \mathrm{~nm}\left(Q_{1}(2)\right.$ line $)$ \\
$\mathrm{HCHO}$ & $(6.08 \pm 0.25) \cdot 10^{-21} \mathrm{~cm}^{2}$ & $308.1034 \mathrm{~nm}$ \\
$\mathrm{SO}_{2}$ & $(1.96 \pm 0.11) \cdot 10^{-20} \mathrm{~cm}^{2}$ & $308.1145 \mathrm{~nm}$ \\
$\mathrm{C}_{10} \mathrm{H}_{8}$ & $(5.90 \pm 1.70) \cdot 10^{-19} \mathrm{~cm}^{2}$ & $308.0020 \mathrm{~nm}$ \\
\hline
\end{tabular}

\subsection{PRECISION OF DOAS. DETERMINATION OF THE MEASUREMENT ERROR}

Measurements of $\mathrm{OH}$ radicals by the absolutely calibrated long-path absorption technique require a reliable determination of the statistical error ('precision') of each measurement. However, the calculation of the precision from the measured absorption spectra is not an easy task. Recently, Stutz and Platt (1996) performed a numerical analysis of the error estimation of DOAS measurements with leastsquares methods. They found that the error calculation using normal linear leastsquares fits is only correct if the assumption of the independence of the measurement error of the individual diode array pixel intensities is fulfilled. However, in many spectra the noise background is not normally distributed. It contains random residual spectral structures (see Figure 3) which are comparable to the shape of trace gas absorptions. These structures may be caused by either etalon effects originating within optical elements (Dorn et al., 1995a) or are detector inherent structures, and/or are caused by unknown molecule absorptions. If such structures appear in the residuals Stutz and Platt (1996) showed that the fitting error calculated by a standard least-squares-fit may lead to an underestimation of the true measurement error by up to a factor of six.

We have developed and tested a statistically sound calculation method for the precision of each individual $\mathrm{OH}$ measurement. Details of this method are described by Hausmann et al. (1997). This method takes into account the residual spectral structures which remain in an air absorption spectrum after removal of all individual contributions of known absorbing trace gases. It assumes that these structures are statistically distributed over the observed spectral range and calculates in a Monte-Carlo simulation their specific influence on the evaluation result of each measured air spectrum. It was shown that for the limiting case of statistically distributed noise (i.e., spectra show only shot noise) this technique and a standard least-squares fit give identical results. 


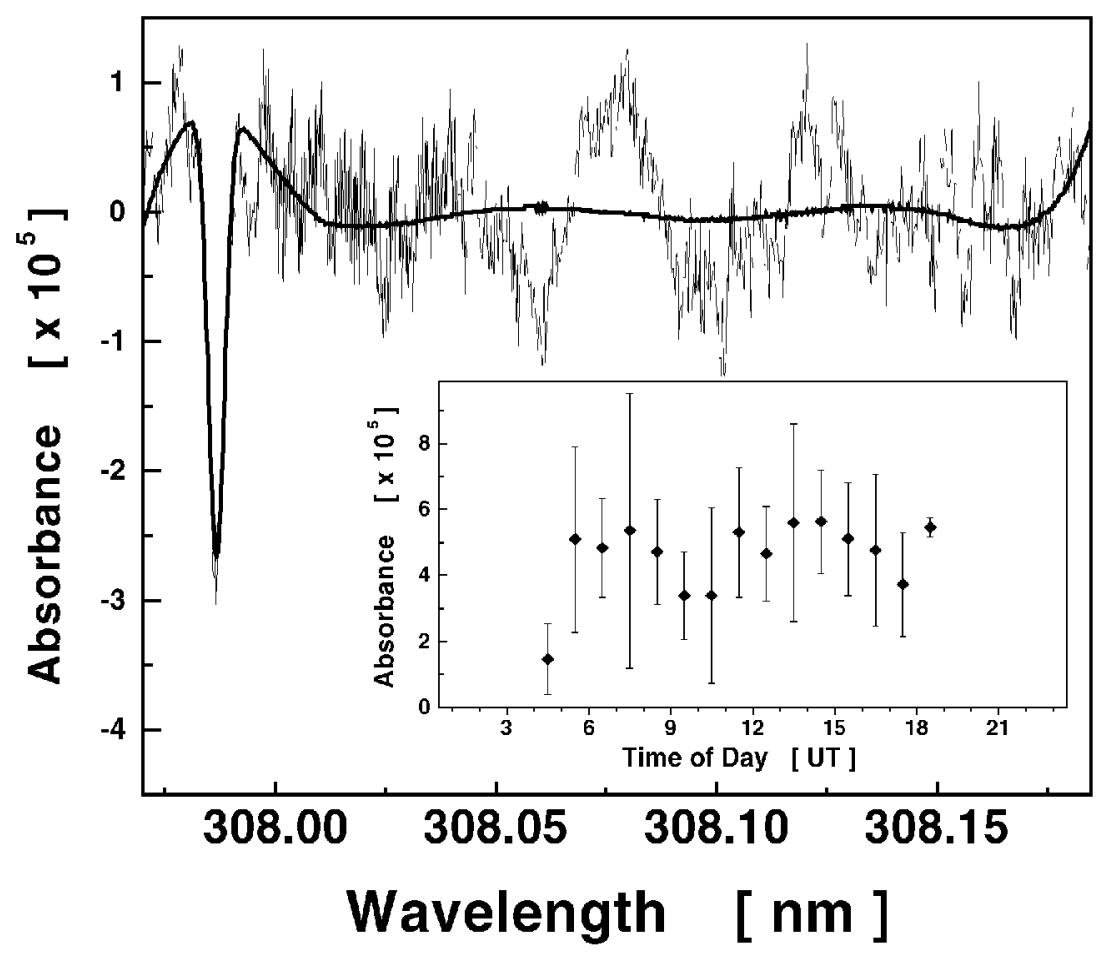

Figure 2. Sum of 58 atmospheric absorption spectra from 16 August 1994 (light path lengths used: $1848 \mathrm{~m}$ and $3080 \mathrm{~m}$ ), from which all absorption signals belonging to $\mathrm{OH}$, naphthalene, sulfur dioxide and formaldehyde are already removed. The residual spectrum shows a single absorption line at $307.9862 \mathrm{~nm}$ (optical density $3.1 \cdot 10^{-5}$, linewidth $4.06 \mathrm{pm}$ ) which originates from absorption of an unknown atmospheric component. All other spectral structures in this residual are noise and detector generated features of very low level (RMS background noise is only $4 \cdot 10^{-6}$ ). Superimposed is a simulated reference spectrum which was generated by fitting a calculated absorption line of appropriate width. Inset: Mean 'diurnal profile' of all 392 measurements of $X$ averaged over 1 hour intervals. Error bars indicate the standard deviation of the mean of each interval.

\section{Results and Discussion}

\subsection{UNKNOWN ABSORPTION LINE IDENTIFIED}

The evaluation of the POPCORN absorption spectra revealed a new, so far not described absorption line of small spectral half width. The absorption line was found in the residuals of most of the campaign spectra after having subtracted the absorption signatures of $\mathrm{OH}, \mathrm{HCHO}, \mathrm{SO}_{2}$, and $\mathrm{C}_{10} \mathrm{H}_{8}$. It is caused by absorption of an up to now unknown atmospheric trace gas (in the following called $X$ ). Figure 2 shows a residual spectrum containing this absorption line at $\lambda=307.9862 \mathrm{~nm}$ (absorbance: $3.3 \cdot 10^{-5}$, line width $4.1 \mathrm{pm}$ ). This spectrum was generated using the sum of 58 residuals of 16 August 1994. Superimposed in Figure 2 is a simulated 
reference spectrum which was obtained from a least-squares fit of an artificial absorption line with an appropriate spectral half width.

$X$ is a real atmospheric component. An instrumental artifact like a detector effect is excluded, since this absorption is fixed to a defined wavelength (demonstrated by rotating the grating) and its observed optical density scales proportional to the light path length according to Lambert-Beer's law. From the field campaign data we found no hint for either a systematic diurnal variation (compare inset in Figure 2) or for a correlation of $X$ with solar radiation or any trace gas measured during the campaign (CO, NMHC, $\mathrm{NO}_{x}$, etc.). The origin of $X$ is still unknown and its appearance is not restricted to the POPCORN site. Reevaluation of our air measurements taken in Jülich in Spring 1994 also show this absorption line, but not as pronounced. In Jülich we used a different set of mirrors, thus a potential interference by the dielectric mirror coatings can be excluded. $X$ was also observed in the atmosphere by two other independent groups. During long-path $\mathrm{OH}$ measurements in Frankfurt and in Mainz W. Armerding et al. (University of Frankfurt) and A. Molz (MPI Mainz) also detected this absorption line (personal communications).

The inclusion of the reference spectrum of $X$ into the retrieval process of the POPCORN spectra has turned out to be important, because the maximum of the absorption line of $X$ (at $307.9862 \mathrm{~nm})$ is located very close $(\Delta \lambda=0.0089 \mathrm{~nm})$ to the strongest $\mathrm{OH}$ absorption line at $307.9951 \mathrm{~nm}$ and thus affects the least-squares fit result for $\mathrm{OH}$. For example, at the median $\mathrm{OH}$ concentration during POPCORN of $4 \cdot 10^{6} \mathrm{OH} / \mathrm{cm}^{3}$ the $\mathrm{OH}$ concentration would be systematically underestimated by $10 \%$. However, the error further depends on the spectral range used for the evaluation procedure (we use a spectral interval of $0.22 \mathrm{~nm}$ ). If this spectral window is only $0.1 \mathrm{~nm}$ (corresponding to the scanning range of the Frankfurt DOAS instrument (Armerding et al., 1994) the relative error of the $\mathrm{OH}$ concentration would already increase to $30 \%$ if the presence of $X$ is ignored.

Older measurements performed with our former $\mathrm{OH}$ instrument during the last years, however, are not affected by $X$ because these measurements used the longer wavelength lines around $308.16 \mathrm{~nm}$ for the $\mathrm{OH}$ detection where we found no absorption of $X$.

\subsection{MEASUREMENTS UNDER DIFFERENT LEVELS OF AIR POLLUTION}

In this section three sets of $\mathrm{OH}$ absorption measurements represent the range of experimental conditions during POPCORN. Figure 3 illustrates measured air absorption spectra from days with (I) very clean air (16 August, $\mathrm{SO}_{2}<0.5 \mathrm{ppb}$ ), (II) slightly polluted air (5 August, $\mathrm{SO}_{2} \approx 4 \mathrm{ppb}$ ), and (III) polluted air (17 August, $\mathrm{SO}_{2}>10 \mathrm{ppb}$ ). The corresponding diurnal concentration profiles are shown later in Figures 7-9.

The absorption spectrum of Figure 3(I) was recorded on 16 August, 1994, 12:38 UT (local summer time 14:38) during a period of remarkably clean air of arctic origin (Koppmann et al., this issue). The observed air spectrum (tracea) 
is dominated by the absorption lines of $\mathrm{OH}$ radicals (trace $d$ shows an $\mathrm{OH}$ reference spectrum). Besides the detector shot noise (high frequency noise background) mainly contributions of formaldehyde were found the strongest absorption lines of which are located between $308.1 \mathrm{~nm}$ and $308.14 \mathrm{~nm}$. These are more clearly shown in trace $b$ which represents the result of the fit of all references to the air spectrum. The air spectrum does not change very much after the removal of the interferences (trace c). The residual (trace e) is free of any trace gas absorption and shows no systematic modulations. The concentrations resulting from the multicomponent analysis (including $X)$ are $\mathrm{OH}=(8.5 \pm 0.5) \cdot 10^{6} \mathrm{~cm}^{-3}$, $\mathrm{HCHO}=(2.8 \pm 0.5) \cdot 10^{10} \mathrm{~cm}^{-3}, \mathrm{SO}_{2}=(5.8 \pm 1.5) \cdot 10^{9} \mathrm{~cm}^{-3}$, and $\mathrm{C}_{10} \mathrm{H}_{8}$ was below the detection limit $\left(\leq 1.5 \cdot 10^{8} \mathrm{~cm}^{-3}\right)$.

Figure 3(II) represents a measurement on 5 August, 1994, 9:01 UT containing moderate absorptions of all absorbing trace species. Trace $a$ shows the air spectrum and trace $b$ represents the product of all reference spectra fitted to the air spectrum. A comparison shows that almost all spectral features are described by the reference spectra used. In order to present the absorption lines due to $\mathrm{OH}$, trace $c$ shows the same spectrum after removal of all absorptions of formaldehyde, sulfur dioxide, naphthalene, and $X$. A comparison with an $\mathrm{OH}$ reference spectrum (trace $d$ ) shows, that all $\mathrm{OH}$ absorption lines are definitely identified. The optical density of the $Q_{1}(2) \mathrm{OH}$ absorption line is $(1.64 \pm 0.13) \cdot 10^{-4}$ and the corresponding concentration is $(9.0 \pm 0.7) \cdot 10^{6} \mathrm{~cm}^{-3}$. The concentrations of $\mathrm{HCHO}, \mathrm{SO}_{2}$, and $\mathrm{C}_{10} \mathrm{H}_{8}$ are $(9.0 \pm 0.7) \cdot 10^{10} \mathrm{~cm}^{-3},(3 \pm 0.2) \cdot 10^{10} \mathrm{~cm}^{-3}$, and $(3.8 \pm 1.2) \cdot 10^{8} \mathrm{~cm}^{-3}$, respectively. The residual (trace e) is dominated by noise $\left(1.5 \cdot 10^{-5} \mathrm{RMS}\right)$. This spectrum is an excellent example for the case where the $\mathrm{OH}$ absorption lines around $308.16 \mathrm{~nm}$, although strong with an optical density of about $1.3 \cdot 10^{-4}$ (see trace c), are almost completely masked by partly anticorrelated $\mathrm{HCHO}$ absorption lines of comparable strength (reference spectra can be found in Dorn et al., 1996). This again demonstrates the advantage of a broad spectral detection interval for the reliable evaluation of complex atmospheric absorption spectra.

Finally a measurement of 17 August is shown which was the most polluted day of the campaign. The high concentrations of sulfur dioxide caused a strong interfering absorption (Figure 3(III), 9:53 UT). The atmospheric spectrum appears to be practically identical with a $\mathrm{SO}_{2}$ reference spectrum. The optical density of the $\mathrm{SO}_{2}$ line at $308.115 \mathrm{~nm}$ is $(1.21 \pm 0.009) \cdot 10^{-3}$ corresponding to $(3.2 \pm 0.02) \cdot 10^{11}$ $\mathrm{cm}^{-3}$. This is a factor of 7 higher than the maximum $\mathrm{OH}$ absorbance in the spectrum of 16 August. Trace $c$ shows the $\mathrm{OH}$ spectrum which appears after removal of the fitted absorption signatures of formaldehyde, sulfur dioxide, naphthalene and $X$. Despite the strong superposition of the $\mathrm{SO}_{2}$ absorption, the $\mathrm{OH}$ absorption lines are clearly retrieved. Trace $d$ shows the fitted $\mathrm{OH}$ reference spectrum. The optical density of the $Q_{1}(2)$ line is $(1.49 \pm 0.16) \cdot 10^{-4}$ corresponding to $(8.2 \pm 0.9) \cdot 10^{6}$ $\mathrm{OH} / \mathrm{cm}^{3}$. The concentrations of $\mathrm{HCHO}, \mathrm{SO}_{2}$, and $\mathrm{C}_{10} \mathrm{H}_{8}$ were $(5.1 \pm 0.9) \cdot 10^{10}$ $\mathrm{cm}^{-3},(3.24 \pm 0.02) \cdot 10^{11} \mathrm{~cm}^{-3}$, and $(6.5 \pm 11.8) \cdot 10^{7} \mathrm{~cm}^{-3}$, respectively. 


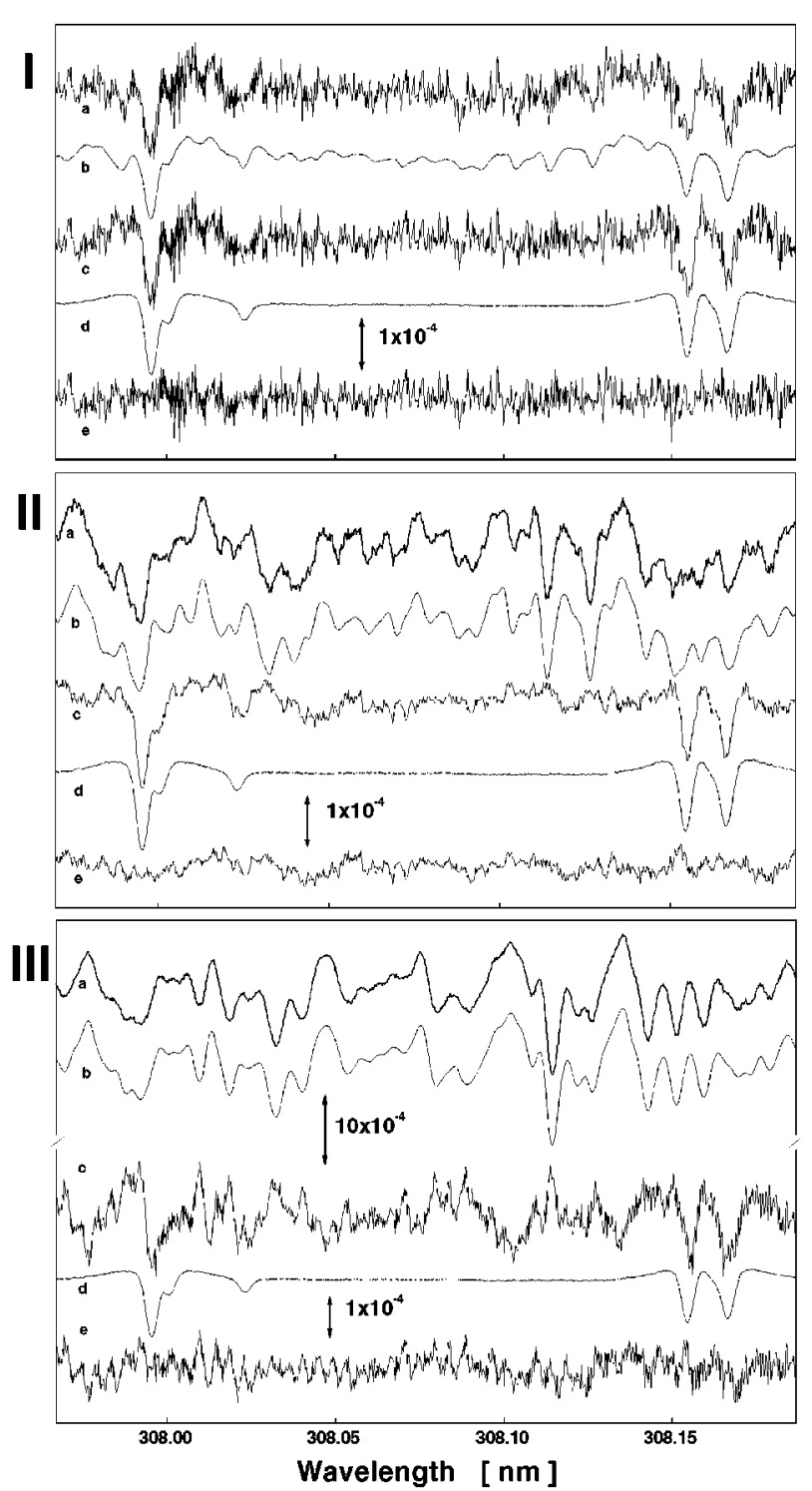

Figure 3. (I) (a) Air spectrum recorded on 16 August 1994 at 12:38 UT; (b) product of all reference spectra (including $X$, see text) fitted to the air spectrum; (c) retrieved spectrum after removal of the absorption contributions of $\mathrm{HCHO}, \mathrm{SO}_{2}, \mathrm{C}_{10} \mathrm{H}_{8}$ and $\mathrm{X}$ except $\mathrm{OH}$; (d) $\mathrm{OH}$ reference spectrum fitted to trace $\mathrm{c}$; (e) residual after removal of all absorption structures from the air spectrum.

(II) (a) Air spectrum recorded on 5 August, 1994 at 09:01 UT; (b) - (e) see above. The arrows in (I) and (II) correspond to an optical density of $1 \cdot 10^{-4}$.

(III) (a) Air spectrum recorded on 17 August, 1994 at 9:53 UT; (b)-(e) see above. The spectrum is dominated by a very strong absorption of $\mathrm{SO}_{2}$. Note the tenfold absorbance scale in (a) and (b). (All air spectra shown in this figure were measured with a light path length of $1848 \mathrm{~m}$ and an integration time of $200 \mathrm{~s}$.) 
In contrast to the air spectra from 5 August and 16 August, the residual spectrum (RMS noise $2.8 \cdot 10^{-5}$ ) additionally contains weak periodic etalon modulations caused by the lenses used with 'optical densities' in the range of $(7-9) \cdot 10^{-5}$. These are responsible for the about $70 \%$ larger error bars for $\mathrm{OH}$ compared with the day before where the absorption spectra were not affected by such modulations (see Figures 7-9 below).

\subsection{DETECTION LIMITS}

As discussed above, the precision of the DOAS measurements is calculated on the basis of the spectral structures which remain in the residual after the subtraction of all fitted references (Hausmann et al., 1997). The $1 \sigma$-detection limit is defined as absorption-to-noise ratio equal one.

Hence each individually calculated precision equals the $1 \sigma$-detection limit of this particular measurement. Since the experimental measurement conditions (atmospheric turbulence, alignment of optical elements, laser stability, visibility, etc.) vary in the course of a field campaign, the detection limit of the instrument is not a constant. We calculated the typical detection limits for the POPCORN campaign from the median of the frequency distribution of the precision of all DOAS measurements. Figure 4 summarizes the observed data. The most frequent occurring detection limits of $\mathrm{OH}$, formaldehyde, sulfur dioxide, and naphthalene were $0.86 \cdot 10^{6} \mathrm{~cm}^{-3}$ (35 ppq), $8.3 \cdot 10^{9} \mathrm{~cm}^{-3}$ (330 ppt), $2.4 \cdot 10^{9} \mathrm{~cm}^{-3}(100 \mathrm{ppt})$, and $1.5 \cdot 10^{8} \mathrm{~cm}^{-3}(6 \mathrm{ppt})$, respectively.

\subsection{DIURNAL VARIATION OF OH, $\mathrm{HCHO}, \mathrm{SO}_{2}, \mathrm{AND} \mathrm{C}_{10} \mathrm{H}_{8}$}

During the POPCORN field campaign, 392 air spectra with $\mathrm{OH}$ were recorded on 16 days between 5 August and 23 August with the long-path absorption instrument. Figure 5 gives an overview of the measured $\mathrm{OH}$ radical concentrations. The peak value observed on 5 August was $12.6 \cdot 10^{6} \mathrm{~cm}^{-3}$, on other days typical noon peak $\mathrm{OH}$ concentrations were around $10 \cdot 10^{6} \mathrm{~cm}^{-3}$. The measurements show distinct diurnal profiles of the $\mathrm{OH}$ concentration reflecting the dependence of $\mathrm{OH}$ on its photochemical production pathways. The evaluation of our former $\mathrm{OH}$ field campaigns already has shown that the main cause of variation in $\mathrm{OH}$ during the day is the photolysis of ozone and, to a lesser extent, the photolysis of aldehydes (Poppe et al., 1993, 1994). The same observation was made during POPCORN (see also Holland et al., this issue). Figure 6 demonstrates the dependence of $\mathrm{OH}$ on the ozone photolysis for 9 August 1994 as indicated by the measured photolysis frequency, $\mathrm{J}\left(\mathrm{O}^{1} \mathrm{D}\right)$. During this day very rapidly changing clouds caused fast and strong modulations of the solar actinic flux. The $\mathrm{OH}$ concentration closely mirrors the fast modulations of the photolysis frequency. The data show that the longpath absorption instrument is capable of resolving the $\mathrm{OH}$ changes (the integration time for a measurement is approximately given by the symbol size in this figure). 

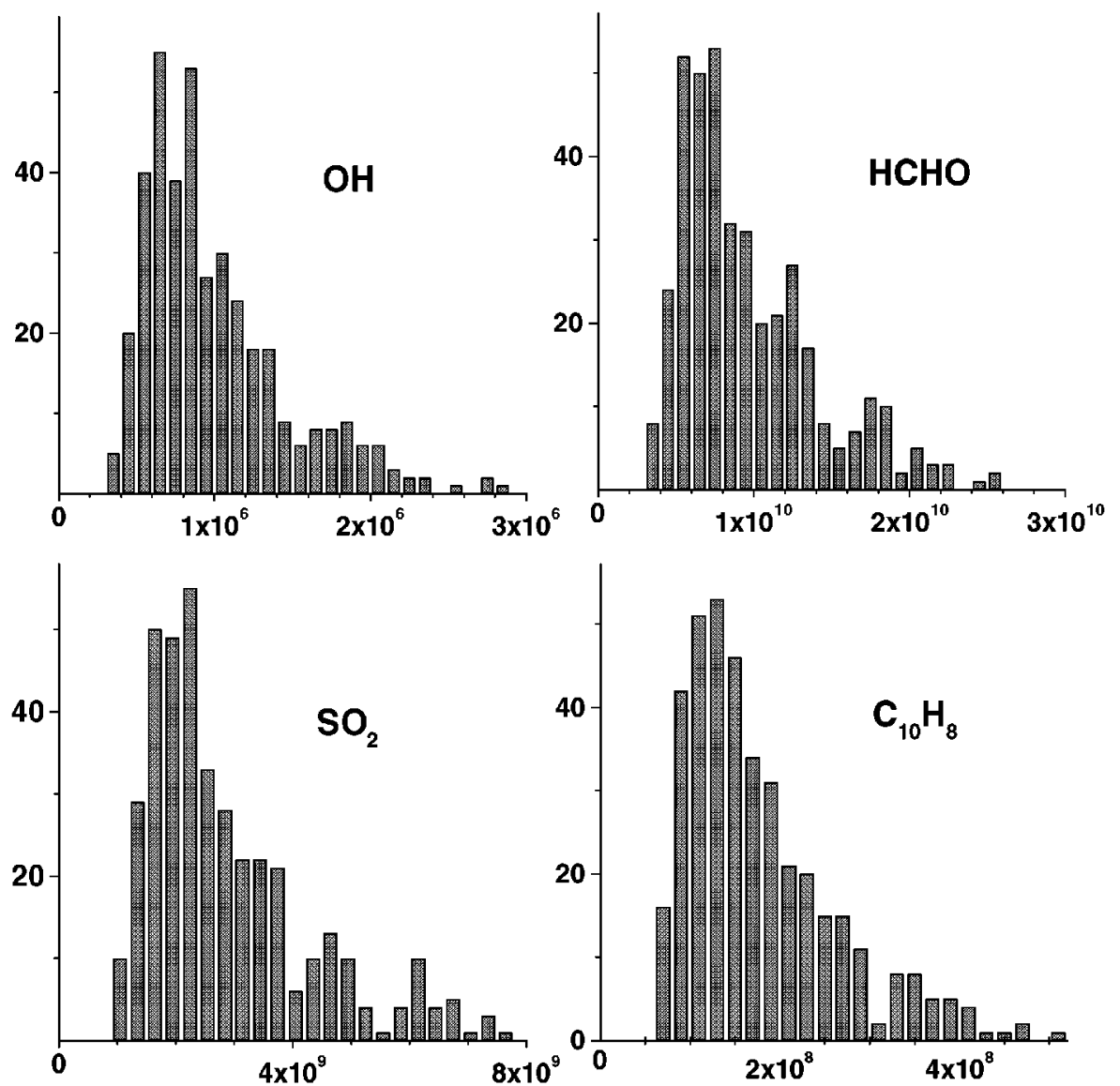

Figure 4. Frequency distribution of the measurement errors, calculated from the noise of the residuals during the field campaign. The medians of these distributions are selected to represent the typical ' $1-\sigma$ ' detection limits for POPCORN: $\mathrm{OH}=0.87 \cdot 10^{6} \mathrm{~cm}^{-3}$; $\mathrm{HCHO}=$ $8.3 \cdot 10^{9} \mathrm{~cm}^{-3} ; \mathrm{SO}_{2}=2.4 \cdot 10^{9} \mathrm{~cm}^{-3} ; \mathrm{C}_{10} \mathrm{H}_{8}=1.5 \cdot 10^{8} \mathrm{~cm}^{-3}$.

Obviously, there are several cases where the simple correlation of $\mathrm{OH}$ with $\mathrm{J}\left(\mathrm{O}^{1} \mathrm{D}\right)$ is not sufficient to explain the observed $\mathrm{OH}$ concentration. Figures 7-9 illustrate the diurnal variations of $\mathrm{OH}, \mathrm{HCHO}, \mathrm{SO}_{2}$, and $\mathrm{C}_{10} \mathrm{H}_{8}$ observed during the three days discussed above. For comparison the primary production rate of $\mathrm{OH}$ from ozone photolysis, $\mathrm{P}(\mathrm{OH})$, is also given:

$$
\mathrm{P}(\mathrm{OH})=\frac{2 \cdot \mathrm{J}\left(\mathrm{O}^{1} \mathrm{D}\right) \cdot\left[\mathrm{O}_{3}\right] \cdot k_{\mathrm{H}_{2} \mathrm{O}} \cdot\left[\mathrm{H}_{2} \mathrm{O}\right]}{k_{\mathrm{O}_{2}} \cdot\left[\mathrm{O}_{2}\right]+k_{\mathrm{N}_{2}} \cdot\left[\mathrm{N}_{2}\right]+k_{\mathrm{H}_{2} \mathrm{O}} \cdot\left[\mathrm{H}_{2} \mathrm{O}\right]}
$$

where $\mathrm{k}_{\mathrm{H}_{2} \mathrm{O}}$ is the reaction constant of $\mathrm{O}^{1} \mathrm{D}$ atoms with water vapor and the term $\mathrm{k}_{\mathrm{O}_{2}} \cdot\left[\mathrm{O}_{2}\right]+\mathrm{k}_{\mathrm{N}_{2}} \cdot\left[\mathrm{N}_{2}\right]$ describes the loss of $\mathrm{O}^{1} \mathrm{D}$ atoms by quenching to $\mathrm{O}^{3} \mathrm{P} . \mathrm{P}(\mathrm{OH})$ also takes into account the diurnal variations of ozone and water vapor.

Figure 7 illustrates the measurements from 16 August 1994. The OH concentration shows a marked diurnal profile with a peak value of $8.9 \cdot 10^{6} \mathrm{~cm}^{-3}$ at $12: 47$ 

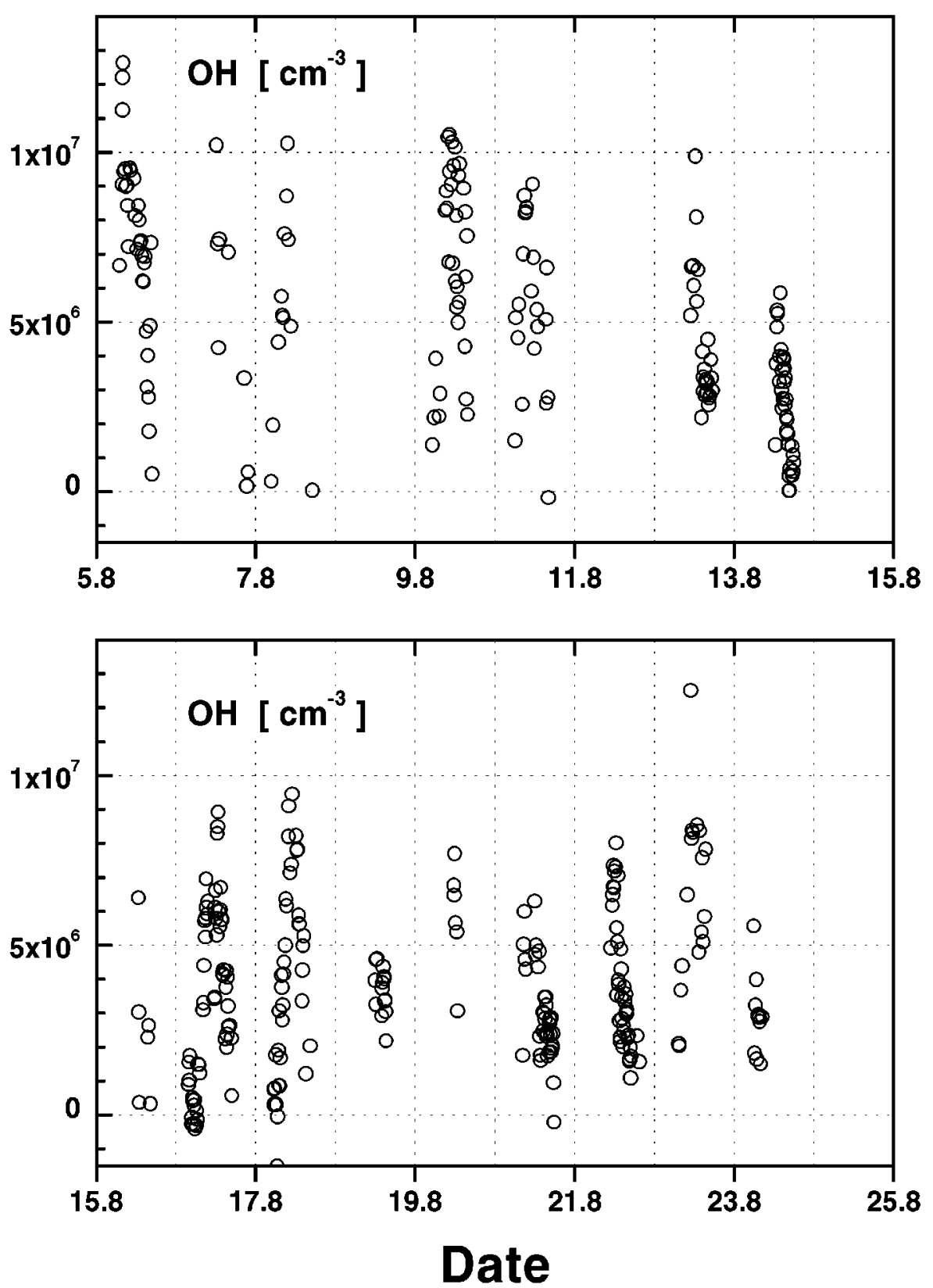

Figure 5. Summary of all $\mathrm{OH}$ measurements by folded long-path laser absorption spectroscopy during POPCORN (392 OH data). Ticks indicate midnight. 


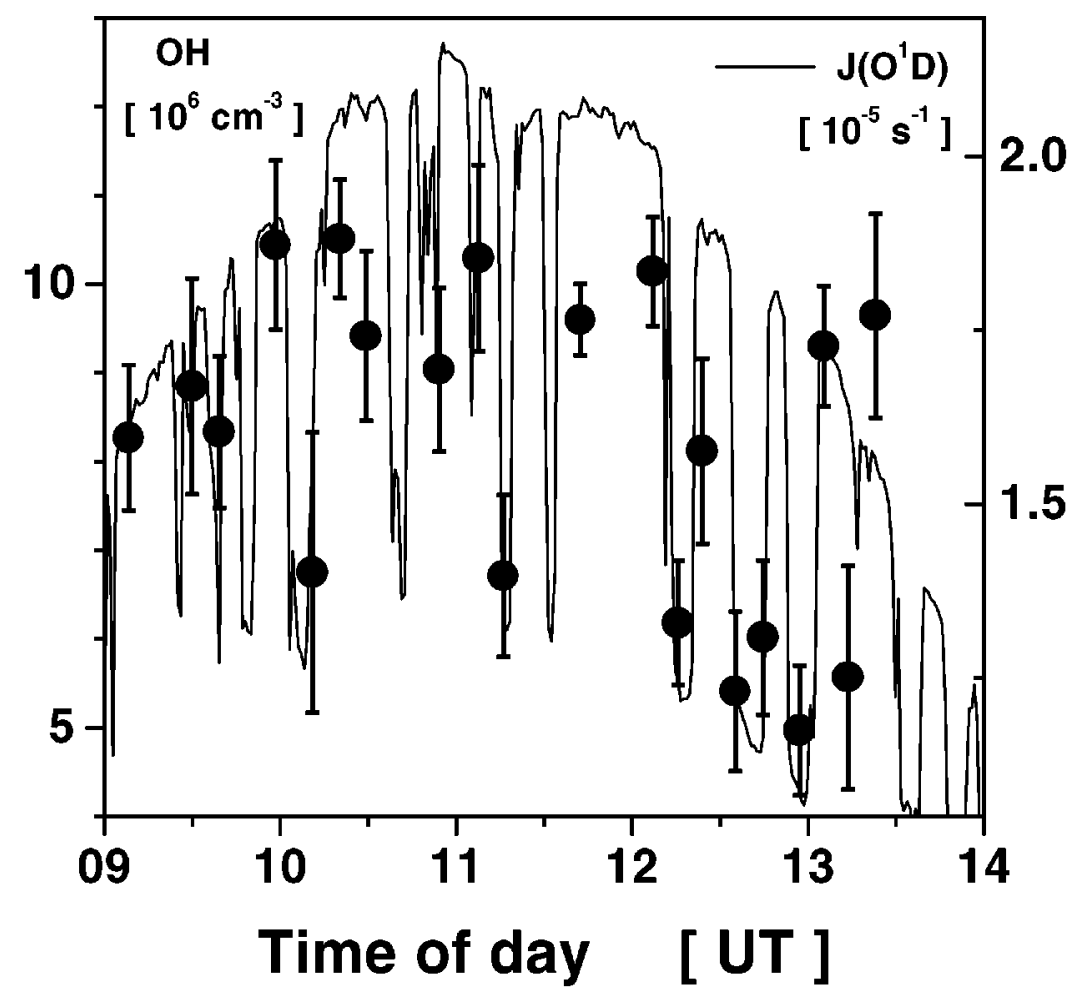

Figure 6. Comparison of the measured $\mathrm{OH}$ concentration and ozone photolysis rate, $\mathrm{J}\left(\mathrm{O}^{1} \mathrm{D}\right)$ on 9 August 1994 . The scale of $\mathrm{J}\left(\mathrm{O}^{1} \mathrm{D}\right)$ was adjusted to approximately match the amplitude of the diurnal $\mathrm{OH}$ variation.

UT. At the beginning of the measurements in the morning (03:47 UT), several air spectra were recorded with $\mathrm{OH}$ concentration values significantly larger than zero. Because $\mathrm{P}(\mathrm{OH})$ is below $10^{3}$ molecules $\cdot \mathrm{cm}^{-3} \mathrm{~s}^{-1}$ at that time these data may indicate a strong secondary $\mathrm{OH}$ production such as photolysis of nitrous acid (HONO). This assumption is supported by the observed decrease of the $\mathrm{OH}$ concentration to zero shortly after sunrise (3:53 UT). By that time, most HONO molecules are expected to be photolysed. Unlike its photolysis frequency, J(HONO), HONO was not measured during the campaign. From earlier field observations of HONO and $\mathrm{NO}_{2}$ in urban areas (Platt et al., 1980; Harrison et al., 1996) one can estimate that about $1-4 \%$ of the nighttime $\mathrm{NO}_{2}$ can be found as $\mathrm{HONO}$ before sunrise. In the present case, $2.7 \mathrm{ppb}$ of $\mathrm{NO}_{2}$ would result in a maximum of $100 \mathrm{ppt}$ of HONO. With the measured photolysis frequency of $\mathrm{J}(\mathrm{HONO})=1.1 \cdot 10^{-5} \mathrm{~s}^{-1}$ at 04:15 UT, the $\mathrm{OH}$ production rate would be $3 \cdot 10^{4} \mathrm{~cm}^{-3} \mathrm{~s}^{-1}$. Thus, under these conditions and taking into account the fast removal of $\mathrm{OH}$ by $\mathrm{NO}_{2}$ at this time (chemical lifetime of $\mathrm{OH}$ due to reaction with $\mathrm{NO}_{2}$ at $2.7 \mathrm{ppb}$ is about $0.6 \mathrm{~s}$ ), this estimate shows that the observed $\mathrm{OH}$ concentrations in the morning are not likely due to the photolysis of HONO. On the other hand, Rohrer and coworkers (this issue) found that the 


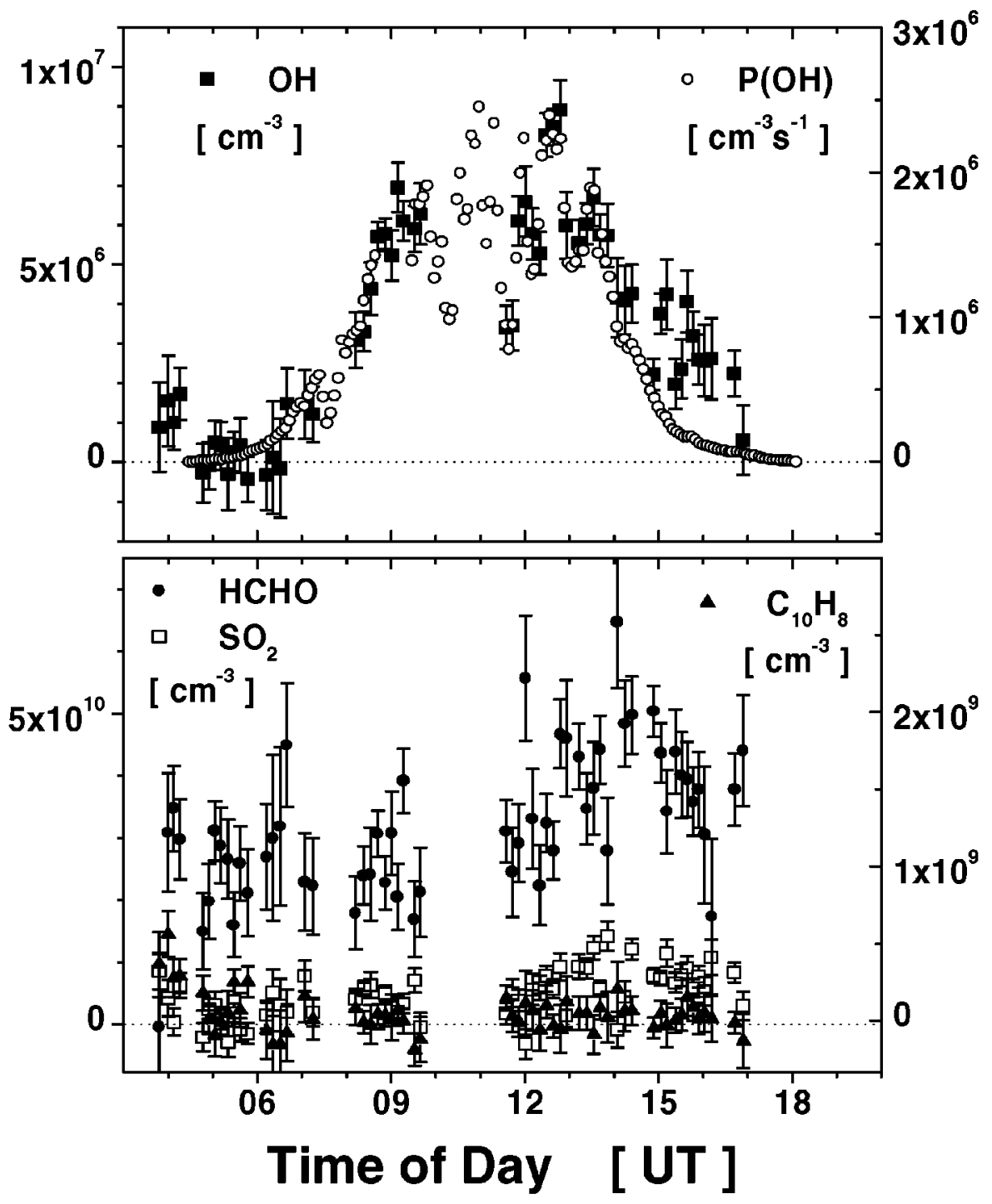

Figure 7. (Top) Diurnal variation of the $\mathrm{OH}$ concentration (filled squares) and the $\mathrm{OH}$ production rate from ozone photolysis, $\mathrm{P}(\mathrm{OH})$, on 16 August 1994 (58 measurements). The peak $\mathrm{OH}$ concentration was $(8.9 \pm 0.8) \cdot 10^{6} \mathrm{~cm}^{-3}$ at $12: 47$ UT. The graph of $\mathrm{P}(\mathrm{OH})$ was scaled to best fit the observed $\mathrm{OH}$ concentration. (Bottom) Diurnal concentration profiles of HCHO (filled dots), $\mathrm{SO}_{2}$ (open squares), and $\mathrm{C}_{10} \mathrm{H}_{8}$ (filled triangles) on 16 August 1994. The 2 hours gap in the DOAS measurements is caused by realignment of the laser system and the White cell. 
local soil was a relatively strong source of NO. Thus, heterogeneous conversion of the formed $\mathrm{NO}_{2}$ into $\mathrm{HONO}$ in the atmospheric layer close to the ground could have caused higher HONO concentrations during the nocturnal inversion.

Later between 04:46 UT and 06:30 UT, OH scatters around zero. This observation is corroborated by a simplified estimate of the expected stationary $\mathrm{OH}$ concentration. On the supposition, that the $\mathrm{OH}$ production is mainly determined by the photolysis of ozone and formaldehyde $\left(\mathrm{P}_{\mathrm{O}_{3}}(\mathrm{OH})=2.5 \cdot 10^{5} \mathrm{~cm}^{-3} \cdot \mathrm{s}^{-1}\right.$ and $\mathrm{P}_{\mathrm{HCHO}}(\mathrm{OH})=3.6 \cdot 10^{5} \mathrm{~cm}^{-3} \mathrm{~s}^{-1}$ at 6:30 UT) and the $\mathrm{OH}$ loss by the reaction with $\mathrm{NO}_{2}\left(\left[\mathrm{NO}_{2}\right] \geq 2 \mathrm{ppb}\right.$ at $\left.6: 30 \mathrm{UT} \sim \tau_{\mathrm{OH}}=0.8 \mathrm{~s}\right)$, the expected stationary $\mathrm{OH}$ concentration is $[\mathrm{OH}]_{\mathrm{stat}}=\mathrm{P}_{\mathrm{tot}}(\mathrm{OH}) \cdot \tau_{\mathrm{OH}} \leq 5 \cdot 10^{5} \mathrm{~cm}^{-3}$. This concentration is below the detection limit of our instrument.

After 6:39 UT, $\mathrm{OH}$ is increasing continuously in good agreement with the $\mathrm{OH}$ production rate. Between 09:00 and 13:00 hours the rapid changing cloud cover introduced strong variations in the $\mathrm{OH}$ production rate. This variation is quantitatively reflected by $\mathrm{OH}$ until 15:00 hours. Then, for a period of 2 hours $\mathrm{OH}$ is significantly higher than expected from $\mathrm{P}(\mathrm{OH})$ exclusively.

These afternoon data are most likely affected by a local $\mathrm{OH}$ source as discussed by Brauers et al. (1996). This assumption is supported by the fact, that the beginning of this event exactly coincides with a change of the wind direction from SW to $\mathrm{N}$. The NW to NNE wind sector $\left(285^{\circ}-20^{\circ}\right)$, however, was identified as being contaminated by an unknown source of $\mathrm{OH}$ radicals which affected predominantly the long-path instrument. The supposition that the higher DOAS OH measurements could be caused by potential self generation due to photolysis of ambient ozone by the laser is not supported by the field observations (see Hofzumahaus et al., this issue). The nature of the source for $\mathrm{OH}$ radicals is still unclear and therefore the data observed in this wind sector were excluded from the $\mathrm{OH}$ instrument intercomparison (Hofzumahaus et al., this issue).

The lower panel of Figure 7 demonstrates the observed mixing ratios of naphthalene, sulfur dioxide and formaldehyde. The $\mathrm{SO}_{2}$ concentrations were close to the detection limit and often below. Naphthalene was generally detected only in the morning after nocturnal inversions. Naphthalene was probably emitted from diesel engines of agricultural machines operating during the night at some kilometers distance. The formaldehyde concentration nearly doubles from about $1 \mathrm{ppb}$ in the morning to $1.8 \mathrm{ppb}$ in the afternoon. The average value of HCHO measured by DOAS during POPCORN was $(2.1 \pm 1.2) \mathrm{ppb}$. This compares well with the average value of $(1.8 \pm 1.0) \mathrm{ppb}$ determined by Benning and Wahner (this issue) who used a derivatisation technique and HPLC chromatography for the measurement of aldehydes.

Figure 8 illustrates the diurnal variation of the $\mathrm{OH}$ concentration on 5 August 1994, a cloudless day of medium air pollution which had the highest photolysis rates of the campaign (Brauers et al., this issue). The peak $\mathrm{OH}$ concentration of $(12.6 \pm 1.8) \cdot 10^{6} \mathrm{~cm}^{-3}$ is observed early in the morning at 08:09 UT. Local noon was at 11:18 hours UT. From the beginning of the measurements at 7:07 UT, the 


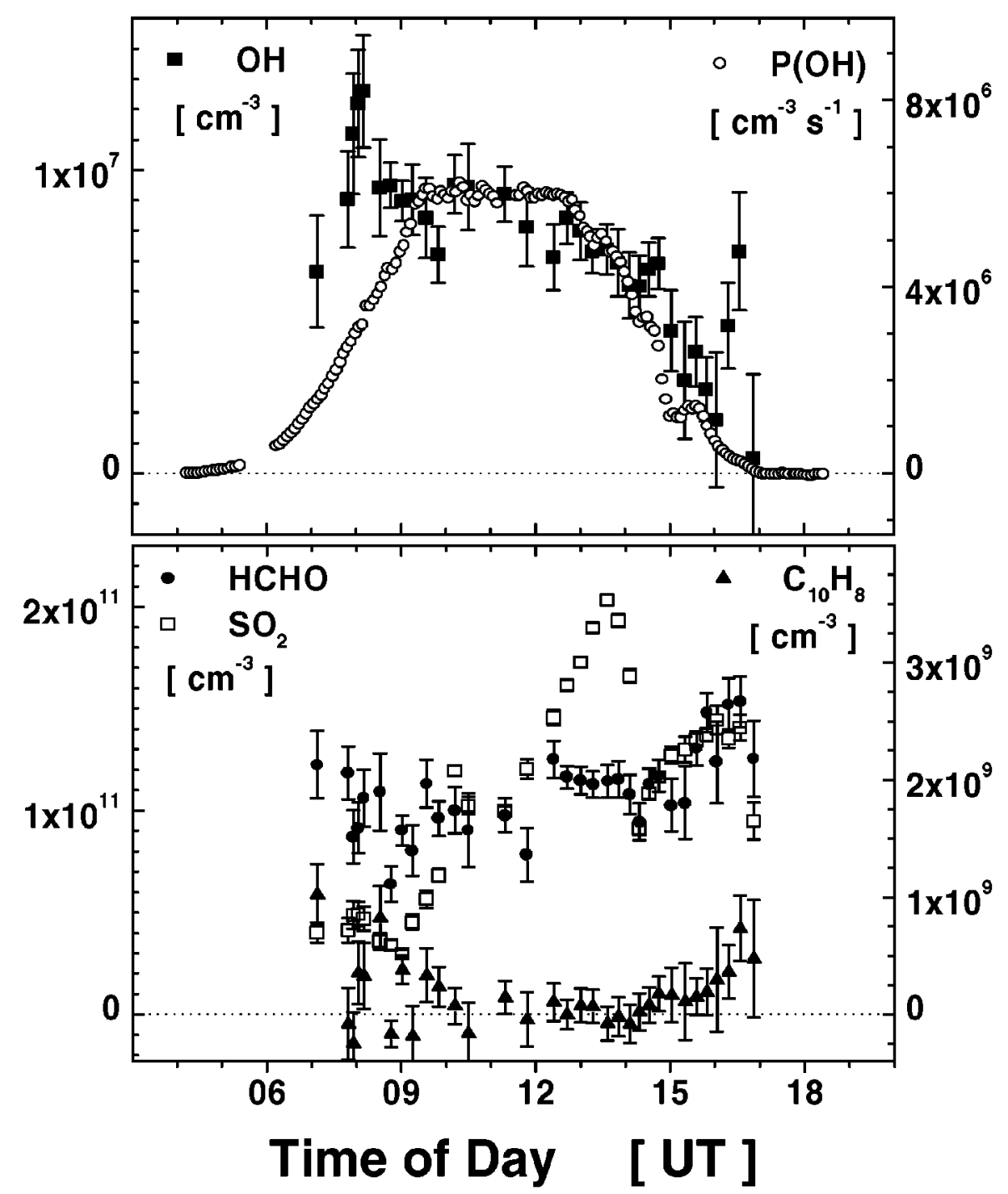

Figure 8. (Top) Diurnal variation of the $\mathrm{OH}$ concentration on 5 August 1994 (33 measurements) showing a peak value of $(12.6 \pm 1.8) \cdot 10^{6} \mathrm{~cm}^{-3}$ at 8:09 UT. Superimposed is the measured $\mathrm{OH}$ production rate from photolysis of ozone (10 min. average values). (Bottom) Diurnal profile of the concentrations of formaldehyde, sulfur dioxide, and naphthalene measured by the long-path absorption instrument.

$\mathrm{OH}$ concentration quickly increases within one hour from $(6.7 \pm 1.8) \cdot 10^{6} \mathrm{~cm}^{-3}$ to the maximum. Thereafter it drops down to a nearly constant value around $9 \cdot 10^{6} \mathrm{~cm}^{-3}$ for a period of about 4 hours and decreases gradually to zero until 17:00 UT. This $\mathrm{OH}$ variation is broadly reflected by the measured primary $\mathrm{OH}$ production rate shown as $10 \mathrm{~min}$ averages. The maximum ozone photolysis rate 
at this day was $2.1 \cdot 10^{-5} \mathrm{~s}^{-1}$. $\mathrm{P}(\mathrm{OH})$ data show a plateau between 09:30 UT and 13:00 UT (average production rate during this period: $6 \cdot 10^{6} \mathrm{OH} \mathrm{cm}^{-3} \cdot \mathrm{s}^{-1}$ ).

The available ancillary measurements do not explain the observed peak $\mathrm{OH}$ concentrations at 08:00 UT. In contrast the two $\mathrm{OH}$ measurements at 16:18 and 16:33 which show a significant deviation from $\mathrm{P}(\mathrm{OH})$ are most likely caused by the same local $\mathrm{OH}$ source as the measurements from 16 August. At 16:05 the wind suddenly changed within 3 minutes from $180^{\circ}$ to $290^{\circ}$ where it remained for 40 minutes before it switched back to south. After that period, the last $\mathrm{OH}$ measurement of this day (16:51) is close to zero as it is expected from the reading of $\mathrm{P}(\mathrm{OH})$ (see also Hofzumahaus et al., this issue).

In the lower panel of Figure 8 the concentrations of formaldehyde, sulfur dioxide, and naphthalene are shown as diurnal profiles. With the exception of some measurements in the morning and afternoon, most of the naphthalene data are zero within their error bars (maximum: $1.1 \cdot 10^{9}$ molec. $/ \mathrm{cm}^{3}$ ). $\mathrm{SO}_{2}$ shows a considerable variation over the day, ranging from $4 \cdot 10^{10} \mathrm{~cm}^{-3}$ at 09:00 UT to $20 \cdot 10^{10} \mathrm{~cm}^{-3}$ at 13:30 UT and $15 \cdot 10^{10} \mathrm{~cm}^{-3}$ in the afternoon. This is not paralleled by the formaldehyde concentration which remains nearly constant during the day ranging from about $10 \cdot 10^{10} \mathrm{~cm}^{-3}$ in the morning to $15 \cdot 10^{10} \mathrm{~cm}^{-3}$ at $16: 30 \mathrm{UT}$.

The $\mathrm{OH}$ concentration on 17 August which was the most polluted day of the campaign again shows a marked diurnal profile (Figure 9). The peak of the $\mathrm{OH}$ concentration $\left(9.5 \cdot 10^{6} \mathrm{~cm}^{-3}\right)$ coincides with the maximum of the $\mathrm{OH}$ production rate $\left(3.2 \cdot 10^{6} \mathrm{OH} \mathrm{cm}^{-3} \cdot \mathrm{s}^{-1}\right)$ at local noon. In the morning the sulfur dioxide concentration increased very rapidly from the background level of $0.5 \cdot 10^{10} \mathrm{~cm}^{-3}$ to a peak value of $40 \cdot 10^{10} \mathrm{~cm}^{-3}$ at 12:30 UT. HCHO ranged between $5 \cdot 10^{10} \mathrm{~cm}^{-3}$ and $10 \cdot 10^{10} \mathrm{~cm}^{-3}, \mathrm{C}_{10} \mathrm{H}_{8}$ remained at the detection limit (one outlier was probably caused by local car exhaust).

Figures 7-9 demonstrate a good correlation between $\mathrm{OH}$ and its primary photochemical formation reaction for the three individual days but also reveal some deviations. Figure 10 compares the mean diurnal profiles averaged over all 16 measurement days of the campaign and binned to one hour intervals. Only measurements performed in the undisturbed wind direction sector between $20^{\circ}$ and $285^{\circ}$ (see Brauers et al., 1996 and Hofzumahaus et al., this issue) were taken into account. The ozone photolysis data used to calculate $\mathrm{P}(\mathrm{OH})$ were limited to the integration times of $\mathrm{OH}$ measurements. In Figure 10 the trace of $\mathrm{P}(\mathrm{OH})$ has been normalized to the peak of the $\mathrm{OH}$ diurnal profile. It appears that the width of the $\mathrm{OH}$ production profile is significantly narrower than the $\mathrm{OH}$ diurnal profile. In the morning $\mathrm{OH}$ rises faster and in the afternoon declines more slowly than the primary $\mathrm{OH}$ production rate. This indicates that secondary $\mathrm{OH}$ production reactions must contribute during these times. Photolysis of formaldehyde which is present at nearly constant level of about 2 ppb during POPCORN is a likely candidate as an additional source of $\mathrm{HO}_{2}$ and thus of $\mathrm{OH}$ radicals. A detailed analysis of the fast photochemical processes during POPCORN using the whole set of ancillary data is in progress. 


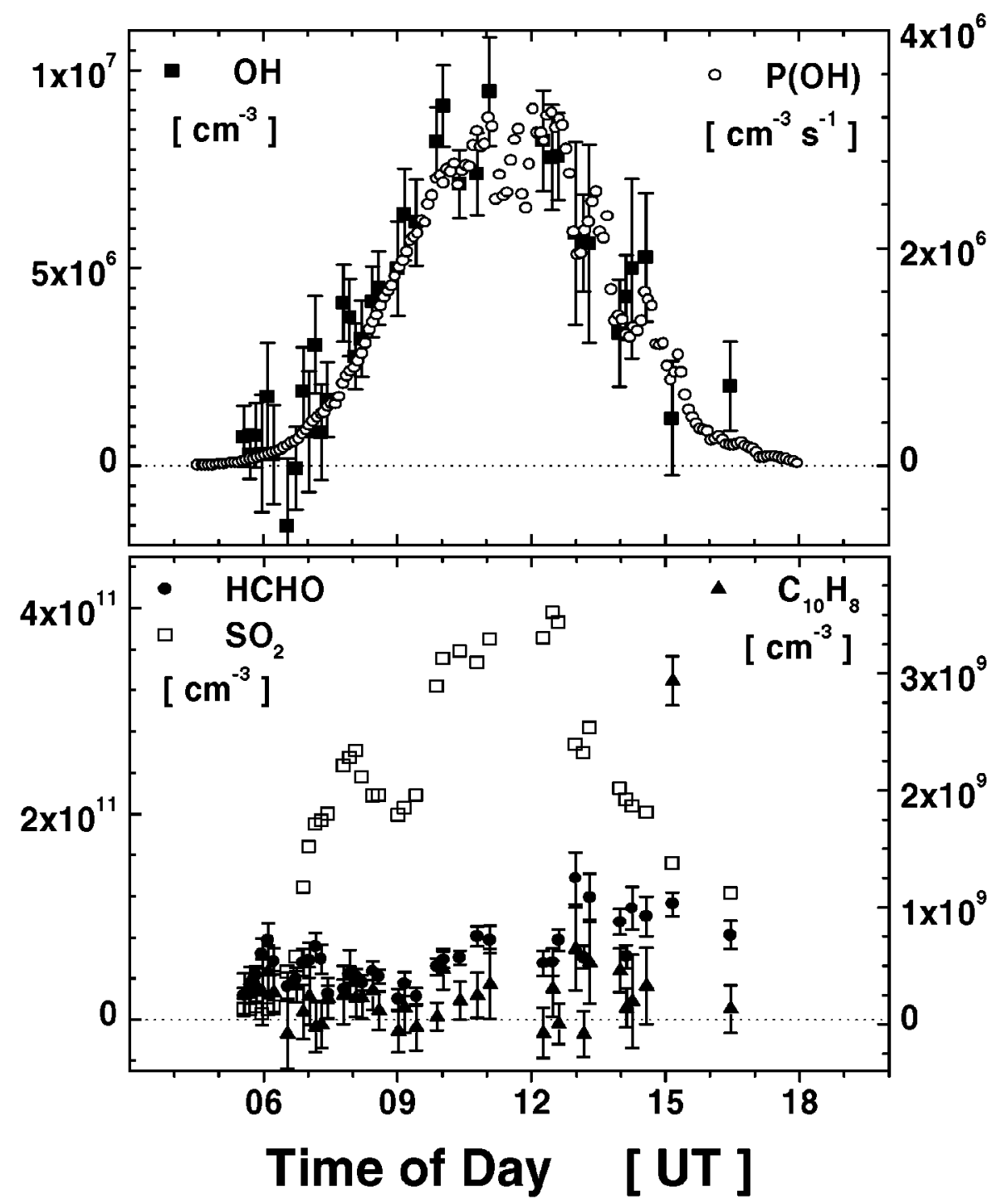

Figure 9. (Top) Diurnal variation of the $\mathrm{OH}$ concentration and the $\mathrm{OH}$ production rate from ozone photolysis on 17 August 1994 (39 measurements) which was the most polluted day during POPCORN. The highest observed $\mathrm{OH}$ concentration was $(9.5 \pm 1.4) \cdot 10^{6} \mathrm{~cm}^{-3}$ at 11:04 UT. (Bottom) Diurnal concentration profiles of $\mathrm{HCHO}, \mathrm{SO}_{2}$, and $\mathrm{C}_{10} \mathrm{H}_{8}$ on $17 \mathrm{Au}-$ gust 1994. In the morning the sulfur dioxide concentration increased very rapidly from about $0.5 \cdot 10^{10} \mathrm{~cm}^{-3}$ to a peak value of $40 \cdot 10^{10} \mathrm{~cm}^{-3}$ at $12: 30 \mathrm{UT}$. 


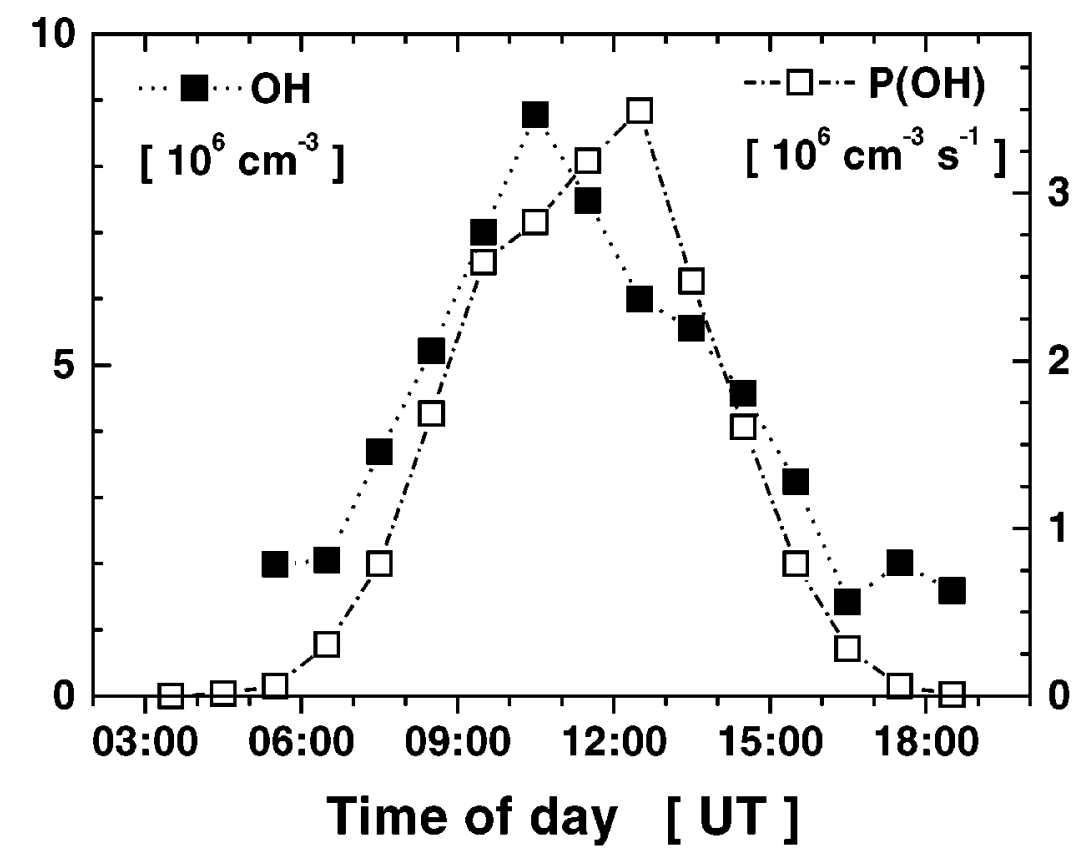

Figure 10. Mean diurnal profiles of $\mathrm{OH}$ (all $\mathrm{OH}$ data measured within a certain wind sector, see text) and the $\mathrm{OH}$ production rate from ozone photolysis, $\mathrm{P}(\mathrm{OH})$. Both data sets are binned to one hour intervals and the $\mathrm{P}(\mathrm{OH})$ data is selected for the times of $\mathrm{OH}$ measurements (the scale of $\mathrm{P}(\mathrm{OH})$ was adapted to the $\mathrm{OH}$ peak value).

\section{Summary and Conclusion}

We have shown that the new folded long-path laser absorption instrument can measure local tropospheric $\mathrm{OH}$ radical concentrations with a time resolution of 200 seconds and with high specificity, sensitivity, and precision even under heavily polluted conditions. This was demonstrated by the measurements on the most polluted day of the field campaign (17 August 1994) when high concentrations of $\mathrm{SO}_{2}$ led to a maximum absorbance ratio of 20 between $\mathrm{SO}_{2}$ and $\mathrm{OH}$ in the air absorption spectra. The uniform size of the error bars in Figure 9 illustrates that the precision of the $\mathrm{OH}$ data was actually unaffected by the level of the $\mathrm{SO}_{2}$ interference.

Like the three examples shown here most diurnal $\mathrm{OH}$ concentration profiles observed during POPCORN show a very good correlation with the $\mathrm{OH}$ production rate from ozone photolysis. Measurements in the morning and evening hours, however, indicate higher $\mathrm{OH}$ concentrations relative to $\mathrm{P}(\mathrm{OH})$. This observation is confirmed by measurements of $\mathrm{OH}$ radicals using laser induced fluorescence described by Holland and coworkers (this issue). At these times other photochemical $\mathrm{OH}$ production reactions must contribute significantly to the local radical budget. The most probable is the photolysis of aldehydes, particularly of formaldehyde, which showed unusually high concentrations during POPCORN (see Benning and 
Wahner, this issue). An analysis using the whole set of ancillary measurements is currently underway.

\section{Acknowledgements}

We are grateful to Christian Plass-Dülmer who organized the POPCORN campaign and to the Wariner Pflanzenbau e.G. for their continuous and friendly support during the campaign. We also thank Martin Müller and Alexander Kraus for providing their ozone and formaldehyde photolysis data.

\section{References}

Armerding, W., Spiekermann, M., and Comes, F. J., 1994: OH multipass absorption: Absolute and in-situ method for local monitoring of tropospheric hydroxyl radicals, J. Geophys. Res. 99, 12251239.

Benning, L. and Wahner, A., 1998: Measurements of atmospheric formaldehyde and acetaldehyde during POPCORN 1994 using 2,4-DNPH coated silica cartridges, J. Atmos. Chem. 31, 105-117.

Brandenburger, U., 1995: In situ Messung troposphärischer Hydroxyl-Radikale mittels LaserLangweg-Absorption in einer optischen Vielfach-Reflexionszelle, Ph.D. thesis, Univ. Bonn, Bonn, Germany.

Brauers, T., Hausmann, M., Brandenburger, U., and Dorn, H.-P., 1995: Improvement of differential optical absorption spectroscopy using Multi-Channel-Scanning-Technique, Appl. Opt. 34, 44724479.

Brauers, T., Aschmutat, U., Brandenburger, U., Dorn, H-P., Hausmann, M., Hessling, M., Hofzumahaus, A., Holland, F., Plass-Dülmer, C., and Ehhalt, D. H., 1996: Intercomparison of tropospheric $\mathrm{OH}$ radical measurements by multiple folded long-path laser absorption and laser induced fluorescence, Geophys. Res. Lett. 23, 2545-2548.

Brauers, T., Dorn, H.-P., Koch, H., Kraus, An. B., and Plass-Dülmer, C., 1998: Meteorological aspects, ozone, and solar radiation measurements during POPCORN 1994, J. Atmos. Chem. 31, $33-52$.

Callies, J., 1988: Absorptionsspektroskopischer Nachweis von Hydroxylradikalen in der Troposphäre: 1988, Ph.D. thesis, Univ. Köln, Köln, Germany.

Cantrell, A. C., Davidson, J. A., McDaniel, A. H., Shetter, R. E., and Calvert, J. G., 1990: Temperature dependent formaldehyde cross sections in the near/ultraviolet spectral region, J. Phys. Chem. 94, 3902-3908.

Crosley, D. (ed.), 1994: Local measurement of tropospheric $\mathrm{HO}_{x}$, NASA Conference Publication 3245.

Dorn, H.-P., Callies, J., Platt, U., and Ehhalt, D. H., 1988: Measurement of tropospheric OH concentrations by laser long-path absorption spectroscopy, Tellus 40B, 437-445.

Dorn, H.-P., Neuroth, R., Brauers, T., Brandenburger, U., and Ehhalt, D. H., 1993: Measurement of tropospheric $\mathrm{OH}$ radical concentrations by differential laser long-path absorption, in H. I. Schiff and U. Platt (eds), Optical Methods in Atmospheric Chemistry, Proc. SPIE Int. Soc. Opt. Eng. 1715, pp. 361-366.

Dorn, H.-P., Brandenburger, U., Brauers, T., and Hausmann, M., 1995a: A new in situ laser longpath absorption instrument for the measurement of tropospheric OH radicals, J. Atmos. Sci. 52, 3373-3380.

Dorn, H.-P., Neuroth, R., and Hofzumahaus, A., 1995b: Investigation of OH absorption cross sections of rotational transitions in the $\mathrm{A}^{2} \Sigma^{+}, v^{\prime}=0 \longleftarrow X^{2} \Pi, v^{\prime \prime}=0$ band under atmospheric 
conditions. Implications for tropospheric long-path absorption measurements, J. Geophys. Res. 101, 7397-7409.

Dorn, H-P., Brandenburger, U., Brauers, T., Hausmann, M., and Ehhalt, D. H., 1996: In-situ detection of tropospheric $\mathrm{OH}$ radicals by folded long-path laser absorption. Results from the POPCORN field campaign in August 1994, Geophys. Res. Lett. 23, 2537-2540.

Ehhalt, D.H., Dorn, H.-P., and Hofzumahaus, A., 1994: J. G. Calvert (ed.), The Measurement of OH Radicals in the Troposphere, Blackwell Scientific Publications, London, pp. 157-173.

Eisele, F. L., Mount, G. H., Fehsenfeld, F. C., Harder, J., Madronicj, E., Parrish, D. D., Roberts, J., Trainer, M., and Tanner, D., 1994: Intercomparison of tropospheric OH and ancillary trace gas measurements at Fritz Peak Observatory, Colorado, J. Geophys. Res. D99, 18605-18626.

Gomer, T., Brauers, T., Heintz, F., Stutz, J., and Platt, U., 1993: MFC Software V1.98, University of Heidelberg and Forschungszentrum Jülich.

Harrison, R. M., Peak, J. D., and Collins, G. M., 1996: Tropospheric cycle of nitrous acid, J. Geophys. Res. 101, 14429-14439.

Hausmann, M., Brauers, T., Brandenburger, U., and Dorn, H.-P., 1997: Detection of tropospheric OH radicals by long-path differential-optical-absorption-spectroscopy: Experimental setup, accuracy, and precision, J. Geophys. Res. 102, 16011-16022.

Hofzumahaus, A., Aschmutat, U., Hessling, M., Holland, F., and Ehhalt, D. H., 1996: The measurement of tropospheric $\mathrm{OH}$ radicals by laser-induced-fluorescence spectroscopy during the POPCORN field campaign, Geophys. Res. Lett. 23, 2541-2544.

Hofzumahaus, A., Aschmutat, U., Brandenburger, U., Brauers, T., Dorn, H.-P., Hausmann, M., Hessling, M., Holland, F., Plass-Dülmer, C., and Ehhalt, D. H., 1998: An intercomparison of tropospheric $\mathrm{OH}$ radical measurements by laser-long-path-absorption and laser-inducedfluorescence spectroscopy during POPCORN 1994, J. Atmos. Chem. 31, 227-246.

Holland, F., Aschmutat, U., Hessling, M., Hofzumahaus, A., and Ehhalt, D. H., 1997: Highly time resolved measurements of $\mathrm{OH}$ during POPCORN using laser-induced fluorescence spectroscopy, this issue.

Koppmann, R., Plass-Dülmer, C., Ramacher, B., and Rudolph, J., 1998: Measurements of carbon monoxide and nonemethane hydrocarbons during POPCORN, J. Atmos. Chem. 31, 53-72.

Kraus, Al. and Hofzumahaus, A., 1998: Field measurements of atmospheric photolysis frequencies for $\mathrm{O}_{3}, \mathrm{NO}_{2}, \mathrm{HCHO}, \mathrm{CH}_{3} \mathrm{CHO}, \mathrm{H}_{2} \mathrm{O}_{2}$, and $\mathrm{HONO}$ by UV spectroradiometry, J. Atmos. Chem. 31, 161-180.

Mount, G. H.: 1992, The measurement of tropospheric OH by long path absorption. 1. Instrumentation, J. Geophys. Res. 97, 2427-2444.

Mount, G. H. and Eisele, F.: 1992, An intercomparison of tropospheric OH measurements at Fritz Peak Observatory, Colorado, Science 256, 1187-1190.

Neuroth, R., Dorn, H.-P., and Platt, U., 1991: High resolution spectral features of a series of aromatic hydrocarbons and $\mathrm{BrO}$ : Potential interferences in atmospheric OH-measurements, J. Atmos. Chem. 12, 287-298.

Neuroth, R.: 1992, Messung troposphärischer Hydroxyl-Radikale mit Laser-LangwegAbsorptionsspektroskopie, Ph.D. thesis, Univ. Bonn, Bonn, Germany.

Perner, D., Platt, U., Trainer, M., Hübler, G., Drummond, J. W., Junkermann, W., Rudolph, J., Schubert, B., Volz, A., Ehhalt, D. H., Rumpel, K. J., and Helas, G., 1987: Measurement of tropospheric $\mathrm{OH}$ concentrations: A comparison of field data with model predictions, J. Atmos. Chem. 5, 185-216.

Plass-Dülmer, C., Brauers, T., and Rudolph, J., 1998: POPCORN: A field study of photochemistry in North-Eastern Germany, J. Atmos. Chem. 31, 5-31.

Platt, U. and Perner, D., 1980: Direct measurements of atmospheric $\mathrm{CH}_{2} \mathrm{O}, \mathrm{HNO}_{2}, \mathrm{O}_{3}, \mathrm{NO}_{2}$, and $\mathrm{SO}_{2}$ by Differential Optical Absorption in the near UV, J. Geophys.Res. 85, 7453-7458.

Platt, U., Rateike, M., Junkermann, W., Rudolph, J., and Ehhalt, D. H., 1988: New tropospheric OH measurements, J. Geophys. Res. 93, 5159-5166. 
Poppe, D., Walasch, M., and Zimmermann, J., 1993: The dependence of the concentration of OH on its precursors under moderately polluted conditions: A model study, J. Atmos. Chem. 16, 61-78.

Poppe, D., Zimmermann, J., Bauer, R., Brauers, T., Brüning, D., Callies, J., Dorn, H.-P., Hofzumahaus, A., Johnen, F.-J., Khedim, A., Koch, H., Koppmann, R., London, H., Müller, K.-P., Neuroth, R., Plass-Dülmer, Ch., Platt, U., Rohrer, F., Röth, E.-P., Rudolph, J., Schmidt, U., Wallasch, M., and Ehhalt, D. H., 1994: A comparison of measured OH concentrations with model calculations, J. Geophys.Res. 99, 16633-16642.

Press, W. H., Teukolssky, S. A., Vetterling, W. T., and Flannery, B. P., 1992: Numerical Recipes in C: The Art of Scientific Computing, Cambridge University Press, 2nd edition, pp. 666-670.

Rohrer, F., Brüning, D., Grobler, E. S., Weber, M., and Ehhalt, D. H., 1998: Mixing ratios and photostationary state of $\mathrm{NO}$ and $\mathrm{NO}_{2}$ observed during the POPCORN field campaign, J. Atmos. Chem. 31, 119-137.

Stutz, J. and Platt, U., 1996: Numerical analysis and estimation of the statistical error of differential optical absorption spectroscopy measurements with least-squares methods, Appl. Optics 35, 6041-6053. 